\title{
フェイス・ツゥ・フェイスのコミュニケーショ ン過程に関する理論的研究
}

\author{
小林潔司 ${ }^{1}$ 福山敬 2 松島格也 ${ }^{3}$ \\ 1正会員 工博 京都大学教授 大学院工学研究科土木工学専攻 ( $=$ 606-8501 京㺃市左京区吉田本町) \\ ${ }^{2}$ 正会員 Ph.D 鳥取大学助教授 工学部社会開発システム工学科 ( \\ 3 正会員 工修 京衩大学助手 大学院工学研究科土木工学専攻 ( 7 606-8501 京衩市左京区吉田本町)
}

\begin{abstract}
本研究では，フエイス・ツゥ・フエイスのコミュニケーション過程が，個人がミーティングを行う相手を求め て探索を行うマッチング過程と、ミーティングを行うかどうかを判断する合意形成過程により構成できること を指摘し，個々人間のミーティング行動をベルマンの最適性原理を用いて表現する. 都市内において長期的な 定常状態において実現するミーティング均衡を，多くの主体による非協力な動的過程における合理的期待均衡 として定義する，さらに，ミーティング均衡の特性について理論的に考察する.
\end{abstract}

Key Words : face-to-face communications, meeting equilibrium, search, rational expectations

\section{1.はじめに}

現代都市には膨大な量のアイデアや知識が集積して いる. 人間の間でのアイデア交換の容易さが, 大都市の 集積の効果という外部経済を形成している. フェイス・ ツゥ・フェイスのコミュニケーションは, 人間がアイデ アや知識を交換するための重要な手段である．この種 のコミュニケーション行動においては, 意思決定プロ セスに相手の意思が関与するという特徴がある.すな わち, ミーティングを行う当事者達が, 互いにミーティ ングを行うことに合意することがコミュニケーション が成立するための前提となる.

ランダム効用モデルを用いた交通行動モデルの発展 により, 交通行動の表現方法の自由度は著しく増加し た.これらの研究は, 交通現象を個々人による独立な行 動に還元し，それを集計化することにより理解しよう という方法論に基づいている. しかし，多くの交通行 動において, 交通主体は他人の意思と無関係にその行 動のすべてを決定できるものではない. 特に, フェイ ス・ツゥ・フェイスのコミュニケーション行動をモデル 化するためには, 従来無視されてきた個人間の意思決 定における相互作用を明示的に考慮する必要がある1).

個人間の意思決定問題に相互作用がある場合, 集計 化操作を個人の選択行動の簡単な加算和では表現でき ない，多くの人間が，互いにミーティングに対するニー ズが一致する相手を発見し，ミーティングに対する合 意を形成し，ミ一ティングを繰り返す。このようなミー ティングの繰り返しにより得られる効用水準も, ミー ティング相手の意思決定の結果に依存して決定される.
ミーティングが形成されるか否かは偶然的な要素にも 左右されよう. フェイス・ツゥ・フェイスのコミュニケー ションのメカニズムを理解するためには, ミーティン グがランダムに繰り返される過程とそこにおける確率 的均衡をモデル化することが重要な課題となる.

本研究では, 人間のフェイス・ツゥ・フェイスのコミュ ニケーションを異なる相手とのミーティングが繰り返 される過程として記述し，その長期的なミーティング 均衡をモデル化する. さらに, 交通施設の整備がミ一 ティング均衡に及ぼす影響について分析する. その際, 最も基本的なミーティングの形態である 2 人ミーティ ングに焦点を絞ることとする．以下，2．では本研究 の基本的な考え方を示す． 3 . で，システム全体での ミーティング過程を，4．で個人のミーティング行動 をモデル化する． 5. ではミーティング均衡について 理論的に考察し, 今後の研究課題をとりまとめる.

\section{2. 本研究の基本的な考え方}

\section{（1）従来の研究の概要}

伝統的な交通行動モデリングでは, 個人の行動を他 人の意思決定とは切り離してモデル化するという方法 論が採用されてきた.もちろん, 他人の意思決定の結果 が個人行動に及ぼす影響が無視されてきたわけではな い. 例えば，確率的ネットワーク均衡2)3)や合理的期待 均衡45)のように, 個人行動の結果は交通ネットワーク のパフォーマンスを通じて集計化された形で個人の効 用に影響を及ぼすように取り扱われてきた。近年，個 
人の意思決定の相互作用を明示的にモデル化するアプ ローチがいくつか提案されている. 小林等6) はランダ ム・マッチングモデルにより個人間の意思決定の相互作 用を直接モデル化している. 森川等は, 他人の効用水 準が reference point となり自分の効用に影響を及ぼす ようなランダム効用モデル7)を提案している. これらの 研究は, 個人の交通行動分析のレベルにとどまってお り, システム全体での均衡を定義できるような一般的 な内容を持ち合わせていない. 著者等の知る限り, 意 思決定の相互作用を考慮したコミュニケーション行動 の確率的均衡を分析した研究事例は見あたらない.

フェイス・ツゥ・フェイスのコミュニケーション過程 においては, ミーティング相手の探索行動が重要な意 味を持つ.このような探索行動に関しては, すでにオぺ レーションズ・リサーチにおいて探索理論8)という確立 した研究分野となっている. 経済活動を行ううえで個 人間の取引が必要不可欠であることから, 経済学の分 野でも探索行動に関する研究が進展している. 例えば, Diamond ${ }^{9}$, Mortensen ${ }^{10)}$ は需要サイドと供給サイド の人間が取引相手を探索するモデルを構築し，その均 衡状態の非効率性を分析している. Howitt ${ }^{11)}$ は, 探索 費用が必要な市場行動を分析し, 取引相手の希少性から 生じる外部不経済について分析している.さらに,これ らの研究成果は, ゲーム理論の分野を中心に two-sided matching game として発展を遂げつつある12)。これら の研究の特徵は, 需要者と供給者という 2 種類の異な るサイドの間の市場取引を分析した点にある. フェイ ス・ツゥ・フェイスのコミュニケーションでは, 各個人 がミーティングの需要者と供給者としての役割を状況に 応じて演じわける点に特幑がある. したがって, フェイ ス・ツゥ・フェイスのコミュニケーション行動をモデル 化するためには，新たに non-sided matching gameに 関する分析枠組みを開発する必要がある.

\section{（2）ミーティング形成の特徽とその分類}

ミーティングを行うためにはまず少なくとも 2 人の 個人がミーティングを行う意思を持って出会う必要が ある.さらに，当該の個人がミーティングを形成する ことに合意しなければならない.つまり, 複数の個人が ミーティング形成に合意するまでの過程（以下，ミー ティング過程と呼ぶ）は，1）ミーティングを行う対 象となりうる相手と出会う過程，2）出会った後双方 がミーティングを行うことに合意する過程で形成され る. 本研究では, 前者の過程を「マッチング過程」, 後 者を「合意形成過程」と呼ぶこととする. ミーティン グは，ミーティングが「自発的になされるか」,「強制的 になされるか」により「自発的ミーティング」,「強制 的ミーティング」に分類できる1). 前者は，友人関係等
の私的交際，あるいは多くのビジネス会合のように該 当する個人の自由意思によって形成されるミーティン グである. 自発的ミーティングは，異なる個人がミー ティングの潜在的な相手と「どのようにして知り合う のか」,「どのように交渉をはじめるのか」を規定する 技術（マッチング技術）によって（3）で述べるよう に分類できる. 一方, 後者はミーティングの当事者の 一方，あるいは第三者が強制力を行使することにより 実現することが義務づけられるようなミーティングで ある. 強制的ミーティングでは, 権力を有する個人や 組織がマッチング開催の詳細を決定する. 以下, 本研 究では個人の自由意思により形成される「自発的ミー ティング」に焦点をあてることとする.

\section{（3）自発的ミーティングとマッチング技術}

自発的ミーティングでは, ミーティング相手を探索 するためのマッチング技術が重要な役割を果たす.マッ チング技術は，異なる個人が時間軸上で出会い合意を 形成していく過程を支えており，1）情報チャンネル， 2) 探索戦略，3）統合ルールにより記述される. 情報 チャンネルとはミーティング相手の存在を見い出すため に個人が利用する情報源を意味し，1）個人情報，2） 組織情報，3）市場情報に大別できる．1）は, ミ一 ティング相手を組織化されない情報に基づいて探索す る方法を意味しており, 最も単純な情報チャンネルで ある. 個人は学会等の組織に参加することにより探索 情報費用を大幅に節約できる，さらに，情報チャンネ ルの技術革新により, 市場でミーティング相手に関す る情報を購入することも可能となろう. 個人がいずれ の情報チャンネルを利用するかは, 情報費用や必要と する知識・情報の内容に依存する.

探索理論8)に基づけば, 個人がミーティング相手を 探索する際に利用する代表的な（停止）戦略として 1) 近視眼的方法，2）代替案を作成する方法，3）選択 肢集合を用いる方法が考えられる. 近視眼的方法とは, 最も簡単な探索戦略であり，ミーティング相手を逐次 探索し自分の保留効用を上回った最初の相手とミーティ ングの交渉を行う戦略である．2）は，いくつかの代 替的な相手を探索しその中から適切な相手を選択する という方法である．3）は常時，交際を行う相手の集 合を確保しておき，その中から適切な相手を選択する という戦略である. 通常, ミーティング相手の探索情 報費用を節約するため, 個人は基本的には探索戦略 3) を採用しながら, 他の探索戦略を併用し相手集合を適 宜修正しているのが実態であろう.

ミーティング過程は時間軸上で繰り返される動的現 象であり, 生起時刻を調整する統合ルールが必要とな る. 統合方式は，1）外生方式，2）逐次決定方式，3） 
ダイヤリー方式に大別できよう，1）では，外生的に ミーティングが計画され，個人は参加するか否かのみ を決定する．2） 3 ）は，基本的に個人がミーティン グ過程を管理する方式である．2）では，相手の探索 とミーティングの実施が相互に繰り返される．3）で は，あたかも個人が手帳の中にミーティング予定を埋 めるようにミーティング過程が調整されていく．ミー ティングは, 情報チャンネル, 探索戦略, 統合ルール の組み合わせにより分類できるが，1つのモデルによ りすべてのタイプのミーティングを表現できるわけで ない. 本研究ではミーティングのプロトタイプとして, 最も単純な「個人情報・近視眼的戦略・逐次決定」方式 による同質な個人集団における 2 人ミーティング過程 をとりあげる．この方式によれば，ミーティング相手 の探索は毎期独立に行われ，ミーティング過程は歴史 に依存しない，現実のミーティング過程の複雑性を考 慮すれば, 本研究では極めて限定されたミーティング 過程に焦点を置いていることは否めない.しかし，こ のような簡単なモデルを用いても，次節で述べるよう なミーティング過程に付随する外部経済性を十分に表 現することが可能であり, 交通施設等の整備がミーティ ング均衡に及ぼす影響を効果的に分析できるという利 点を有している．なお，本論文で提案するモデルを拡 張することにより, より複雑なミーティング過程を表 現することが可能になるが，このようなモデルの拡張 性についてはのちに5.（5）で考察する.

\section{（4）ミーティングと外部不経済}

前述したように，ミーティングが成立するためには ミーティング相手の合意を得ることが前提となる．あ る個人がミーティングに合意しない場合, ミーティン グ相手がミーティングに賛同していてもミーティング は実現しない. その結果, 個人の行動が他人の行動に 影響を直接及ぼすことになる。このような個人間の意 思決定の相互性に起因して, 同質な個人により繰り返 されるミーティング過程には，1）混雑現象，2）市場 薄現象 (thin market phenomena) ${ }^{11)}$ という外部不経済 が存在する．1）は, 都市内の個人のミーティング頻 度が高くなると結果的に混雑が生じ，ミーティング相 手を探索するための情報費用が高くなるという外部不 経済である．一方，2）は，ミーティング相手を選別 することにより生じる外部性である. 個人がミーティ ング過程においてより大きな効用を得るためには，よ り大きな効用をもたらす相手を選択する必要が生じる. しかし，より魅力的なミーティングを実現しようとす れば，ミーティング相手を発見することは困難となり， ミーティング相手の合意を得ることも難しくなる.これ はミーティング市場においてミーティングを取引する
相手が少なくなる外部不経済であり，取引費用の経済 学の分野で市場薄の外部不経済性11) といわれているも のに他ならない.のちに，5.（3）で考察するように， 市場薄の外部不経済性はミーティング均衡の成立に対 して極めて重要な役割を果たすことになる．以上の外 部不経済性は多くのミーティング過程に付随する本質 的な外部不経済性である．本研究で提案するモデルは 極めて単純な構造を有しているが，これら 2 種類の外 部不経済性を効果的に表現できるという利点を持って いる.

\section{3. ミーティング過程のモデル化}

\section{(1) モデル化の前提}

同質な個人が 2 人ミーティングを繰り返すミーティ ング過程をとりあげる．個人はミーティング相手に関 する記憶を持たない. いま，ある都市内に $2 m+1$ 人 の個人が生活し，互いにミーティングの相手を個人的 な情報に基づいて探索していると考えよう.ここでは， 記述の簡略化のため, 個人数を奇数 $2 m+1$ に設定する が，個人数が十分多くなればこの仮定は問題にはなら ない. 各個人は「ミーティングの相手が見つかったり」， あるいは「他人からミーティングに対する申し込みが あった」場合, 当該の相手とミーティングを行うかどう かを判断する. 双方の当事者が，ミーティング形成に 合意した場合は，そこで探索行動は打ち切られ，直ち にミーティングが形成される.ミーティング形成に関 する合意が成立しなかった場合，両者ともミーティン グ相手の探索を再び開始する. ミーティングが形成さ れた場合，ある時間が経過すればミーティングが終了 し， 2 人の個人は互いに離ればなれになり，再びミー ティングの相手を捜し始める. ミーティングの最中は, 探索行動は一時中止される．また，ミーティングの申 し込みがあっても申し出を断ることとする．また，探 索過程において, 過去にミーティングを行った相手と 再びミーティングを形成することを妨げない，すなわ ち，探索過程において，過去にミーティングを形成し たことのある相手とそうでない相手を区別しない，以 下では，すべての個人がこのようなミーティングの形 成を繰り返す過程を出生・死减過程として記述しょう.

\section{（2）ミーティング過程のモデル化}

ある時刻 $t$ において $2 n+1(0<2 n+1 \leq 2 m+1)$ 人 がミーティングを行っておらず, $2(m-n)$ 人がミーティ ングを行っていると考える. 各個人には $2 n$ 人の（自分 以外の）潜在的な交渉相手が存在している. ミーティン グの形成・終了する事象が稀少であり，ある微小時間 $\Delta t$ の間に 2 組以上のミーティングが形成される（ある 
いは 2 組以上のミーティングが終了する，あるいはそ の両方が生起する）確率を無視できるものとする.す なわち，ある時刻 $t$ から微小時間 $t+\Delta t$ の間におこり うる状態の変化としては，1）1組のミーティングが成 立する，2）１組のミーティングが解消される，3）そ のどちらもおこらない，のいずれかである. 時刻 $t$ にお いて, ミーティングを行っていない各個人が $2 n$ 人の潜 在的なミーティングの交渉相手を有しているとき，あ る微小時間 $\Delta t$ においてミーティングが形成される割合 を $a(n), 1$ 組のミーティングが終了する割合を $b(n)$ で 表そう.これらの割合は, いずれも潜在的なミーティン グの交渉相手の数 $2 n$ に依存している. $a(n), b(n)$ の具 体的な形式は次節で特定化する. 時刻 $t+\Delta t$ において, ミーティングを行っていない個人が $2 n$ 人のミーティン グ相手を有している確率 $P_{t+\Delta t}(n)(n=0,1, \cdots, m)$ は, 出生死滅過程

$$
\begin{gathered}
P_{t+\Delta t}(0)=a(1) \Delta t P_{t}(1)+(1-b(0) \Delta t) P_{t}(0) \\
+o(\Delta t) !, \quad(1 \mathrm{a}) \\
P_{t+\Delta t}(n)=a(n+1) \Delta t P_{t}(n+1)+b(n-1) \Delta t \\
\cdot P_{t}(n-1)+[1-a(n) \Delta t-b(n) \Delta t] P_{t}(n) \\
\quad+o(\Delta t) !, \quad(n=1,2, \cdots, m-1) \quad(1 \mathrm{~b}) \\
P_{t+\Delta t}(m)=b(m-1) \Delta t P_{t}(m-1)+[1-a(m) \Delta t] \\
\cdot P_{t}(m)+o(\Delta t) !, \quad \text { (1c) } \\
\sum_{n=0}^{m} P_{t}(n)=1
\end{gathered}
$$

により記述される.ここに, $o(\Delta t) !$ !高次の微小項であ る. 式(1a)-(1c)の両辺を $\Delta t$ で割り, $\Delta t \rightarrow 0$ の極限で $\lim _{\Delta t \rightarrow 0} o(\Delta t) ! / \Delta t=0$ が成立すれば次式を得る.

$$
\begin{aligned}
& \dot{P}(0)=a(1) P(1)-b(0) P(0), \\
& \dot{P}(n)=a(n+1) P(n+1)+b(n-1) P(n-1) \\
& \quad-[a(n)+b(n)] P(n),(n=1,2, \cdots, m-1)(2 \mathrm{~b}) \\
& \dot{P}(m)=b(m-1) P(m-1)-a(m) P(m) \quad(2 \mathrm{c}) \\
& \sum_{n=0}^{m} P(n)=1,
\end{aligned}
$$

ただし, $\dot{P}(n)=\lim _{\Delta t \rightarrow 0}\left\{P_{t+\Delta t}(n)-P_{t}(n)\right\} / \Delta t$ であ る. $a(n) \geq 0, b(n) \geq 0$ が成立するとき, $t \rightarrow \infty$ の極 限でシステム (2a)-(2c) は定常状態に収束する. 定常状 態では, $\dot{P}(n)=0(n=0, \cdots, m)$ であり,

$$
\begin{aligned}
& b(0) P(0)=a(1) P(1), \\
& a(n+1) P(n+1)+b(n-1) P(n-1) \\
& \quad=[a(n)+b(n)] P(n)(n=1,2, \cdots, m-1)(3 \mathrm{~b}) \\
& b(m-1) P(m-1)=a(m) P(m)
\end{aligned}
$$

を得る. 式 $(3 \mathrm{a}),(3 \mathrm{~b}),(3 \mathrm{c})$ より帰納的に次式が成り立つ. $a(n+1) P(n+1)=b(n) P(n) \quad(n=1, \cdots, m-1)(4)$
漸化式 $(4)$ を境界条件 $(3 a)$ (3c) 及び条件 $(2 \mathrm{~d})$ の下で解く ことにより, 定常確率は次式で表される.

$$
\begin{aligned}
& P(0)=\frac{\prod_{i=1}^{m} a(i)}{\prod_{i=1}^{m} a(i)+\sum_{k=2}^{m}\left\{\prod_{i=k}^{m} a(i) \prod_{j=0}^{k-2} b(j)\right\}+\prod_{j=0}^{m-1} b(j)}(5 \mathrm{a}) \\
& P(n)=\prod_{l=1}^{n} \frac{b(l-1)}{a(l)} P(0)(n=1, \cdots, m-1) \\
& P(m)=\frac{\prod_{j=0}^{m-1} b(j)}{\prod_{i=1}^{m} a(i)+\sum_{k=2}^{m}\left\{\prod_{i=k}^{m} a(i) \prod_{j=0}^{k-2} b(j)\right\}+\prod_{j=0}^{m-1} b(j)}(5 \mathrm{c})
\end{aligned}
$$

\section{（3）ミーティングの生成・死滅割合}

時刻 $t$ で $2 n+1$ 人がミーティング相手を探索してい ると考える. 彼らは, 自分以外の $2 n$ 人の潜在的な交涉 相手とミーティングを行う可能性を持っている. しか し, 当該の個人は誰がミーティングを行っていないか という情報を事前には持ちえず, 結局, 自分以外の $2 m$ 人全員を対象としてミーティング相手の探索を行わな ければならない. ミーティングの交渉相手と出会う機 会として，1）本人の探索により相手を発見する場合 と2）相手からミーティングの申し込みがある場合が

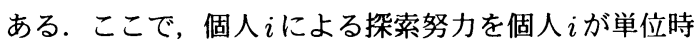
間当たりに相手を発見する確率測度 $\alpha_{i}$ （以下，探索強 度と呼ぶ）を用いて表現しよう. 本人の努力によりミー ティングの交渉相手を発見する確率は当該時刻におい てミーティングを行っていない相手が個人全体に占める 割合 $2 n / 2 m$ に依存すると考えよう. 微小時間 $[t, t+\Delta t]$ にミーティング相手を発見する確率 $s_{i} \Delta t$ は

$$
s_{i} \Delta t=\alpha_{i} \frac{n}{m} \Delta t
$$

と表せる. $s_{i}$ は単位時間当たりにミーティングの交渉相 手を発見する確率測度である.すべての個人が対称的 であり，探索強度がすべて同一であると仮定しよう．個 人 $i$ 以外の代表的個人（他人）の探索強度を $\alpha^{i}$ 亡表す. 個人 $i$ は変数 $\alpha_{i}$ を制御できるが, 他人の探索強度 $\alpha^{i}$ を 制御することはできないため, 変数 $\alpha_{i}$ と $\alpha^{i}$ を区別する. このとき, 自分を除く $2 n$ 人が探索強度 $\alpha^{i}$ でミーティン グ相手を探索しているときに，そのなかの 1 人が微小 時間 $[t, \Delta t]$ において自分自身を発見してくれる確率は $\left(\alpha^{i} / 2 m\right) \Delta t$ である. したがって, $2 n$ 人のうち, 誰か 1 人からミーティングの申し込みを受ける確率 $s^{i} \Delta t$ は

$$
s^{i} \Delta t=\alpha^{i} \frac{n}{m} \Delta t
$$

と表せる.ここに， $s^{i}$ は単位時間当たりにミーティング の交渉相手として発見される確率測度である.したがっ 
て, 個人 $i$ がマッチング相手と $[t, t+\Delta t]$ において出会 う確率 $h_{i}(n) \Delta t$ は次式で表される.

$$
h_{i}(n) \Delta t=\left(\alpha_{i}+\alpha^{i}\right) \frac{n}{m} \Delta t
$$

形成されたマッチングペアにおいて当事者同士がミー ティングに同意し，ミーティングが形成される確率を $\pi_{i}$ としよう。ミーティングが形成されるか否かという合意 は瞬時に形成されると仮定すれば，微小時間 $[t, t+\Delta t]$ においてミーティングが形成される確率 $\xi_{i}(n) \Delta t$ は

$$
\xi_{i}(n) \Delta t=\pi_{i}\left(\alpha_{i}+\alpha^{i}\right) \frac{n}{m} \Delta t
$$

で表される. マッチング過程において, 双方がミーティ ングを行うことに合意すればその時点で探索行動は中 止され，直ちにミーティングが形成される，一方，ミー ティングに対する合意が成立しなかった場合には再び 探索行動を始める.ここで, 個人が対称的であり定常 状態において, $\xi_{i}(n)=\xi(n), \pi_{i}=\pi, \alpha_{i}=\alpha, \alpha^{i}=\hat{\alpha}$ が 成立すると仮定しよう. 時刻 $t$ にミーティングを行って いない $2 n+1$ 人が互いに独立にミーティング相手を探 索するとき, 都市システム全体の中で $\Delta t$ にミーティン グが新しく形成される確率は次式のようになる.

$$
\begin{aligned}
& a(n) \Delta t=\frac{\xi(n)(2 n+1) \Delta t}{2} \\
&=\pi(\alpha+\hat{\alpha}) \frac{n(2 n+1)}{2 m} \Delta t
\end{aligned}
$$

一方, ミーティングの継続時間が平均継続期間長 $\beta^{-1}$ の指数分布に従うと仮定する. $t$ 期に $m-n$ 個のミー ティングが行われ, 単位時間 $\Delta t$ 中にミーティングが 終了する確率 $b(n) \Delta t$ は, 次式のように表せる.

$$
b(n) \Delta t=\beta(m-n) \Delta t
$$

\section{4. 個人のミーティング行動のモデル化}

\section{（1）ミーティング合意形成行動}

マッチング相手の探索は主として, 情報・通信ネット ワークを用いて行われると考える. マッチング相手と のアポイントメントがとれれば, ミーティングが形成 されフェイス・ツゥ・フェイスのコミュニケーションが 行われる. ミーティング場所までの移動には交通ネット ワークが用いられる1). ミーティングが開催されるか否 かに関わらず，ミーティング相手を探索するためには 情報費用が必要となる. 一方, 交通費用はミーティン グが開催される場合にのみ必要となる.

交通ネットワーク上で行われるミーティング行動を モデル化しよう. いま, 個人 $i$ と個人 $j$ が出会い, 互い にミーティングを行うか否かを決定しようとする場面 を考える.「ミーティングを行う」,「ミーティングを行 わない」という 2 つの純粋戦略をもっている. ミーティ ングは 2 人が同時に「ミーティングを行う」という戦 略を選択した場合にのみ形成される. ミーティングの
ための場所, 費用負担等も重要な合意形成項目である. このような合意形成問題は, bargaining game ${ }^{13)}$ を用い ることによるアプローチが可能であるが，ここでは，簡 単化のためにミーティングに要する費用は当事者が互 いにある一定額を負担すると仮定する.

いま, 時刻 $t$ において個人 $i$ が個人 $j$ とミーティング を開始すると考えよう. 時刻 $t$ の現在価值で評価した期 間長 $T$ のミーティングの効用をランダム効用モデル

$$
\begin{aligned}
U_{i}^{j}(t: & \left.T, \varepsilon_{i}^{j}\right) \\
& =\int_{t}^{T}\left(\bar{v}_{i}^{j}+\varepsilon_{i}^{j}\right) \exp \{-r(\tau-t)\} \mathrm{d} \tau-c_{i}^{j} \\
& =\frac{\bar{v}_{i}^{j}+\varepsilon_{i}^{j}}{r}\{1-\exp [-r(T-t)]\}-c_{i}^{j}
\end{aligned}
$$

で表現する. なお, $r$ は時間的割引率, $v_{i}^{j}$ は個人 $i$ が個人 $j$ と会うことにより得られる瞬間効用, $\varepsilon_{i}^{j}$ は個々のミー ティングに特有な瞬間効用 (確率変数) であり,これ らはミーティング期間中は一定值をとる. 時刻 $[t, T]$ で 開催されるミーティングの効用を時刻 $t$ で計測した現在 価值は時刻 $\tau \in[t, T]$ の瞬間効用を時刻 $t$ に割引いた值 $\left(\bar{v}_{i}^{j}+\varepsilon_{i}^{j}\right) \exp \{-r(\tau-t)\}$ を期間 $[t, T]$ に対して積分した 値として定義される. 一方, $c_{i}^{j}$ はミーティング費用（交 通費用）でありミーティングが開始された時点で支払 われる. ミーティング費用は個人 $i, j$ のう, どちらが ミーティングを申し出るかにより異なった值をとるが, 前述したようにミーティングをどちらが申し込んだか によらず一定值をとると考えよう. ミーティングの交渉 時点でミーティング期間長は確定せず, 平均 $\beta^{-1}$ の指数 分布に従うことだけが判っている. この時, 時刻 $t$ の現 在価値で評価したミーティングの期待効用 $E U_{i}^{j}\left(t: \varepsilon_{i}^{j}\right)$ は次式で表される.

$$
\begin{aligned}
E U_{i}^{j} & \left(t: \varepsilon_{i}^{j}\right) \\
& =\int_{t}^{\infty} U_{i}^{j}\left(t: T, \varepsilon_{i}^{j}\right) \beta \exp \{-\beta(T-t)\} \mathrm{d} T \\
& =\gamma\left(\bar{v}_{i}^{j}+\varepsilon_{i}^{j}\right)-c_{i}^{j}
\end{aligned}
$$

なお, $\gamma=1 /(r+\beta)$ である. 個人 $i$ は個人 $j$ とのミ一 ティングで得られる期待効用 $E U_{i}^{j}\left(t: \varepsilon_{i}^{j}\right)$ がある保留効 用水準 $H_{i}$ より大きいときにのみミーティングに合意す る. 保留効用水準は各個人がミーティングを行うか否 かを判断する基準を意味するが, その決定メカニズム は後述する. 個人 $i$ が個人 $j$ とのミーティングに合意す る確率は

$$
\begin{aligned}
p_{i}^{j} & =\operatorname{Prob}\left\{E U_{i}^{j}\left(t: \varepsilon_{i}^{j}\right) \geq H_{i}\right\} \\
& =\operatorname{Prob}\left\{\gamma\left(\bar{v}_{i}^{j}+\varepsilon_{i}^{j}\right)-c_{i}^{j} \geq H_{i}\right\}
\end{aligned}
$$

で表される.一般性を失うことなく, $\varepsilon_{i}^{j}$ は平均値 0 分 散 1 の標準正規分布に従うと仮定する.ここで, 標準 正規分布関数を $\Phi(\cdot)$ により表すと, 個人 $i, j$ のミーティ 
ングの合意確率 $p_{i}^{j}$ はそれぞれ次式で表される.

$$
\begin{aligned}
p_{i}^{j} & =\operatorname{Prob}\left\{\gamma\left(\bar{v}_{i}^{j}+\varepsilon_{i}^{j}\right)-c_{i}^{j} \geq H_{i}\right\} \\
& =\Phi\left(\bar{v}_{i}^{j}-\delta\left(c_{i}^{j}+H_{i}\right)\right) \\
p_{j}^{i} & =\operatorname{Prob}\left\{\gamma\left(\bar{v}_{j}^{i}+\varepsilon_{j}^{i}\right)-c_{j}^{i} \geq H_{j}\right\} \\
& =\Phi\left(\bar{v}_{j}^{i}-\delta\left(c_{j}^{i}+H_{j}\right)\right)
\end{aligned}
$$

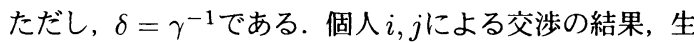
起する事象としては 1 ) 両者ともにミーティングに合意 する（状況 $\Omega_{1} ） ， 2 ）$ 個人 $i$ は合意するが $j$ は拒否をす る（状況 $\Omega_{2} ） ， 3$ ）個人 $j$ は合意するが $i$ は拒否をする $\left(\right.$ 状況 $\left.\left.\Omega_{3}\right) ， 4\right)$ 両者ともに拒否をする（状況 $\Omega_{4} ） ， の$ 4 通りが存在する. いま, 式(15a),(15b)において, ラ ンダム効用項 $\varepsilon_{i}^{j}$ が互いに独立であると仮定しよう.こ の時, 各状況が生起する確率 $P\left(\Omega_{i}\right)(i=1, \cdots, 4)$ は,

$$
\begin{aligned}
& P\left(\Omega_{1}\right)=p_{i}^{j} p_{j}^{i} \\
& P\left(\Omega_{2}\right)=p_{i}^{j}\left(1-p_{j}^{i}\right) \\
& P\left(\Omega_{3}\right)=\left(1-p_{i}^{j}\right) p_{j}^{i} \\
& P\left(\Omega_{4}\right)=\left(1-p_{i}^{j}\right)\left(1-p_{j}^{i}\right)
\end{aligned}
$$

と表せる. ミーティングが生起する確率は式(16a)で 表せる.このような合意確率は，例えばランダムマッ チングモデル6)を用いて記述できる．個人の同質性の 仮定より，個人行動が対称的であり，任意の $i$ に対して $H_{i}=H, \bar{v}_{i}^{j}=\bar{v}, c_{i}^{j}=c, \varepsilon_{i}^{j}=\varepsilon, \pi_{i}^{j}=\pi, E U_{i}^{j}=E U$ が成立すると考える．両者がミーティングに合意する 確率は次式で表せる.

$$
\pi(H, \hat{H})=\Phi(\bar{v}-\delta(c+H)) \Phi(\bar{v}-\delta(c+\hat{H}))
$$

$\hat{H}$ は他人が決定する保留効用水準であり, 合意形成 確率 $\pi$ は本人と他人の保留効用水準 $(H, \hat{H})$ に依存し ている. 正規確率密度関数 $\phi(\varepsilon)$ に対して $\int \varepsilon \phi(\varepsilon) d \varepsilon=$ $-\phi(\varepsilon), \phi(\varepsilon)=\phi(-\varepsilon), \Phi(\varepsilon)=1-\Phi(-\varepsilon)$ が成立するこ とより, ミーティングの期待効用の平均値 $E V(H)$ は

$$
\begin{aligned}
E V(H) & =\frac{\int_{\delta(H+c)-\bar{v}}^{\infty} E U(t: \varepsilon) \phi(\varepsilon) \mathrm{d} \varepsilon}{\int_{\delta(H+c)-\bar{v}}^{\infty} \phi(\varepsilon) \mathrm{d} \varepsilon} \\
& =\gamma \bar{v}-c+\gamma \frac{\phi(\bar{v}-\delta(c+H))}{\Phi(\bar{v}-\delta(c+H))}
\end{aligned}
$$

となる.ここに, $\phi(\cdot)$ は正規確率密度関数である.すな わち, ミーティングの期待効用はミーティングの純付 加価値 $\gamma \bar{v}-c$ とミーティング相手を保留効用 $H$ に基づ いて選別することにより得られるプレミアム（式(18) の第 3 項）の和として表現される.

\section{（2）最適探索行動の決定}

任意の時刻において, 各個人は都市内で形成されて いるミーティングの数を正確には知ることはできない. 個人は各時刻を通じて交渉相手が個人全体に占める真 の割合 $n / m$ を知りえない. 各個人は不確実な環境の下
で意思決定を繰り返し，長期的な学習過程を通じて交 涉相手の個人全体に占める割合の期待値 $E[n / m]$ に関 する合理的期待を形成しうる。このような合理的期待 形成の問題は 5. (1) で改めて議論することとし, 以 下ではひとまずすべての個人はある共通の主観的期待 $E^{s}[n / m]$ を有していると考えよう. 添字 $s$ は主観的期 待であることを表している. この時, 彼が計画するマッ チングの主観的実現確率は

$$
q(\alpha, \hat{\alpha}) \Delta t=(\alpha+\hat{\alpha}) E^{s}\left[\frac{n}{m}\right] \Delta t
$$

と表せる. ただし， $\hat{\alpha} は$ 他人の平均的探索強度を表す。 対称性の仮定より $\alpha=\hat{\alpha}$ が成立するが，変数を支配して いる主体を明確にするために当面両者を区別する．式 (19)に示すように, マッチングが形成される確率は当 人だけでなく他人の探索強度にも依存する.

時刻 $t$ でミーティング相手を探索している個人の期待 生涯効用を $V(t)$ と表そう. 時刻 $t$ に期間長 $T$ のミーティ ングを開始した場合の生涯効用 $\bar{U}(t: T, \varepsilon)$ は, ミーティ ング効用の現在価值と時刻 $t+T$ の期待生涯効用を時刻 $t$ の現在価值に割り引いた結果の期待値の和

$$
\bar{U}(t: T, \varepsilon)=U(t: T, \varepsilon)+V(t+T) \exp \{-r(T-t)\}
$$

で表される. ここで, ミーティング期間長 $T$ が平均 $\beta^{-1}$ の指数分布に従う時, 期待生涯効用は

$$
\overline{E U}(t, \varepsilon)=\int_{t}^{\infty} \bar{U}(t: T, \varepsilon) \beta \exp \{-\beta(T-t)\} \mathrm{d} T(20)
$$

となる. さらに, $\varepsilon$ 確率変数であることを考慮すれば, 最終的に時刻 $t$ にミーティングを開始した時の期待生涯 効用 $R(t)$ は次式のようになる.

$$
R(t)=\frac{\int_{\delta(c+H)-\bar{v}}^{\infty} \overline{E U}(t, \varepsilon) \phi(\varepsilon) \mathrm{d} \varepsilon}{\int_{\delta(c+H)-\bar{v}}^{\infty} \phi(\varepsilon) \mathrm{d} \varepsilon}
$$

時間 $[t, t+\Delta t]$ で生起する事象は， 1$)$ ミーティングが 開始される（事象 $\omega_{1} ） ， 2$ ) マッチングは生起するが ミーティングに失敗する（事象 $\omega_{2} ） ， 3$ ）マッチングに 失敗する（事象 $\omega_{3}$ ）の 3 通りであり, それぞれの生起 確率 $p\left(\omega_{1}\right), p\left(\omega_{2}\right), p\left(\omega_{3}\right)$ は以下のようになる.

$$
\begin{aligned}
& p\left(\omega_{1}\right)=\pi(H, \hat{H}) q(\alpha, \hat{\alpha}) \Delta t \\
& p\left(\omega_{2}\right)=\{1-\pi(H, \hat{H})\} q(\alpha, \hat{\alpha}) \Delta t \\
& p\left(\omega_{3}\right)=\{1-q(\alpha, \hat{\alpha})\} \Delta t
\end{aligned}
$$

個人が時点 $t$ に探索を行っている場合, 時刻 $t+\Delta t$ に確 率 $p\left(\omega_{1}\right)$ で期待生涯効用 $R(t+\Delta t)$, 確率 $p\left(\omega_{2}\right)+p\left(\omega_{3}\right)$ で期待生涯効用 $V(t+\Delta t)$ を獲得する. この時, 個人の 最適探索行動はBellmanの最適性原理 ${ }^{14)}$ より

$$
\begin{aligned}
& V(t)=\max _{\alpha \geq 0, H}\left\{-C(\alpha) \Delta t+\frac{\pi(H, \hat{H}) q(\alpha, \hat{\alpha}) \Delta t}{1+r \Delta t}\right. \\
& \left.\cdot R(t+\Delta t)+\frac{1-\pi(H, \hat{H}) q(\alpha, \hat{\alpha}) \Delta t}{1+r \Delta t} V(t+\Delta t)\right\}
\end{aligned}
$$


と表せる. ただし, $q(\alpha, \hat{\alpha})=(\alpha+\hat{\alpha}) E^{s}[n / m]$ である. また, $C(\alpha)$ は探索情報費用関数であり，

$$
C(0)=0, \frac{\partial C(\alpha)}{\partial \alpha} \geq 0, \frac{\partial^{2} C(\alpha)}{\partial \alpha^{2}} \geq 0
$$

を満足すると仮定する. 式(23) の右辺は, 第 1 項より それぞれ 1 ）探索情報費用，2）ミーティングに成功 した場合の期待生涯効用の現在価値，3）ミーティン グに失敗した時の期待生涯効用の現在価值を表す.式 (23) において定常状態を仮定し $\Delta t \rightarrow 0$ の極限をとれば 再帰方程式

$$
\begin{aligned}
r V= & \max _{\alpha \geq 0, H}\{-C(\alpha) \\
& +\pi(H, \hat{H}) q(\alpha, \hat{\alpha})[E V-\rho V]\}
\end{aligned}
$$

を得る（付録Ｉ参照）。ただし， $\rho=r /(r+\beta), E V$ は ミーティングの期待効用の平均值 (18) であり保留効用 水準 $H$ の関数である. また, $E V(H)-\rho V$ は 1 回のマッ チングがもたらす期待生涯効用である.ここで, 式 $(25)$ の右辺を最大化する問題を考えよう. 他人の保留効用水 準，及び探索戦略がある水準 $\hat{H}, \hat{\alpha} に$ 固定されだ考え る. また, 個人は近視眼的に行動し, $\partial E^{s}[n / m] / \partial \alpha=0$ が成立すると仮定する.いま, 期待生涯効用が $\bar{V}$ の水準 に設定されていると考えれば, 問題

$$
\begin{aligned}
Z=\max _{\alpha \geq 0, H}\{-C(\alpha) \\
\quad+\pi(H, \hat{H}) q(\alpha, \hat{\alpha})[E V(H)-\rho \bar{V}]\}
\end{aligned}
$$

の 1 階の最適化条件は次式で与えられる.

$$
\begin{aligned}
& \frac{\partial \pi(H, \hat{H}) q(\alpha, \hat{\alpha})\{E V(H)-\rho \bar{V}\}}{\partial H}=0 \\
& \frac{\partial C}{\partial \alpha}=\pi(H, \hat{H}) \frac{\partial q(\alpha, \hat{\alpha})}{\partial \alpha}\{E V(H)-\rho \bar{V}\}
\end{aligned}
$$

式 (17),(18) を用いて最適化条件 (27a) を展開すれば

$$
(\rho \bar{V}-H) q(\alpha, \hat{\alpha}) \phi(\bar{v}-\delta(c+H))=0
$$

を得る.ここで, $q(\alpha, \hat{\alpha}) \phi(\bar{v}-\delta(c+H))>0$ が成立す ることに着目すれば, 最適保留効用水準 $H^{*}$ は

$$
H^{*}=\rho \bar{V}
$$

と表せる. $\rho \bar{V}$ は期待生涯効用が $\bar{V}$ の時のミーティング の平均機会費用であり, 平均ミーティング期間長の時間 価値を期待生涯効用を用いて評価した值で表せる. こ こで, 最適保留効用水準 $H^{*}$ は期待生涯効用 $\bar{V}$ 与件と して求めたことに留意しよう.このことを明示的に示 すために, 式 (29) を用いて最適化条件 (27b) を書き換 える.これまで, 他人の保留効用水準, 及び探索戦略 がある水準 $\hat{H}, \hat{\alpha} に$ 固定されていると考えていた. ここ で,すべての個人の期待生涯効用が $\bar{V} に$ 固定されている と仮定しょう.この時, すべての個人は対称的な最適 戦略 $H^{*}(\bar{V}), \alpha^{*}(\bar{V})$ をとることになる. そこで, 最適戦 略 $H^{*}(\bar{V})$ を式 $(17),(18)$ に代入することによりミーティ ングの最適合意確率 $\pi^{*}(\bar{V})=\pi\left(H^{*}(\bar{V}), \hat{H}^{*}(\bar{V})\right)$, 最適
期待効用 $E V^{*}(\bar{V})=E V\left(H^{*}(\bar{V})\right)$ は期待生涯効用 $\bar{V}$ の 関数として

$$
\begin{aligned}
& \pi^{*}(\bar{V})=\Phi(\bar{v}-\delta c-r \bar{V})^{2} \\
& E V^{*}(\bar{V})=\gamma \bar{v}-c+\gamma \frac{\phi(\bar{v}-\delta c-r \bar{V})}{\Phi(\bar{v}-\delta c-r \bar{V})}
\end{aligned}
$$

と書き換えることができる. 一方, 最適戦略 $\alpha^{*}(\bar{V})$ は 最適化条件 $(27 \mathrm{~b})$ より限界期待便益と限界費用が等し くなる水準で決定される.ここで, 式(19),(30),(31)を 考慮すれば, 最適化条件 (27b) は次式のように書き換え ることができる.

$$
\frac{\partial C}{\partial \alpha}=\pi^{*}(\bar{V}) E^{s}\left[\frac{n}{m}\right]\left\{E V^{*}(\bar{V})-\rho \bar{V}\right\}
$$

上式を満足するような最適探索強度を $\alpha^{*}(\bar{V})$ と表そう. 以上では, 期待生涯効用 $\bar{V}$ を件として, 最適な保留効 用水準, 探索強度を求める問題を考えた. 一方, Bellman の最適性原理より期待生涯効用は式 (25) を満足しなけ ればならない.すなわち, 次式が成立する.

$$
\begin{aligned}
r \bar{V}=- & C\left(\alpha^{*}(\bar{V})\right)+\pi^{*}(\bar{V}) q\left(\alpha^{*}(\bar{V}), \hat{\alpha}^{*}(\bar{V})\right) \\
& \cdot\left\{E V^{*}(\bar{V})-\rho \bar{V}\right\}
\end{aligned}
$$

すべての個人が所与の主観的期待 $E^{s}[n / m]$ の下で, 式 $(32),(33)$ を同時に満足するような探索戦略 $\alpha^{*}(\bar{V})$ と均 衡水準 $\bar{V}$ を達成した時, ミーティング過程は均衡状態に あると考えることができる.ここで, 探索戦略, 均衡 水準が変化すれば, それと対応して期待值 $E^{s}[n / m]$ が 変化することに着目しょう.したがって, ミーティング 過程の長期均衡状態を定義するためには, 個人の主観 的期待 $E^{s}[n / m]$ の均衡状態を定義する必要がある.

\section{5. ミーティング均衡}

\section{（1）ミーティング過程の特性}

ミーティング過程では, ミーティング相手の探索とマ ッチングされた相手との合意形成が繰り返される.ミー ティングから得られる効用は, 相手と出会った時点で 明らかになるが, 相手を探索している段階ではその值 を確定的に把握することはできない. さらに, ミーティ ング過程では, 特定の相手と交渉が繰り返されるので はなく相手がランダムに代わっていく. 相手との交渉の 結果を逐一記憶していくことは不可能に近い.このよ うな状況の中で個々人が完全な合理性を追求するとは 考えにくい. むしろ, 限られた情報獲得能力の中で, 主 観的期待や行動を逐次修正していくと考えた方が現実 的であろう. このような限定合理性の下で, 各個人の行 動は，互いに調整されやがて定常政策に収束していく 15). 各プレーヤは各時刻において, 実現するであろう ミーティングにおいて獲得できる効用水準や真のミー ティング形成確率について確実な情報を持ち得ない．こ のような不確害な情報の中で知り得る情報は, ミーティ 
ングで獲得できる期待効用とミーティングの長期的な 形成頻度のみである．このような不確実な環境の下で 各個人は意思決定を繰り返しながら，意思決定環境に 関して合理的期待 16$)$ を形成し最適な探索政策を採用す る. ミ一ティング形成確率に関する主観的期待が合理的 期待に収束するとともに, 個々人の探索戦略は長期的 な定常政策に収束していくと考える.このような最適 な長期定常戦略を, 合理的期待均衡5)の下での定常ナッ シュ均衡として定式化してみよう.

\section{（2）合理的期待均衡}

微小時間におけるミーティング生成・死减強度がそ れぞれ式(10),(11) で表されるとき, 式(5a)-(5c)より, マッチングされた相手がミーティングを行っていない 確率（以下，遭遇確率と呼ぶ）は次式で定義される.

$$
E\left[\frac{n}{m}\right]=\frac{\sum_{n=0}^{m} n x^{n} \psi(n)}{\sum_{n=0}^{m} m x^{n} \psi(n)}=f(x)
$$

なお, $x=\beta /\{\pi(\alpha+\hat{\alpha})\}, \psi(n)=\prod_{i=1}^{n} m(m-$ i) $/\{i(2 i+3)\}, \psi(0)=1$ であり, $E[n / m]$ は $x=$ $\beta /\{\pi(\alpha+\hat{\alpha})\}$ の関数 $f(x)$ を用いて表現できる. 個人の 対称性 $(\alpha=\hat{\alpha})$ を考慮すれば, $x=\beta /\{2 \pi \alpha\}$ と表せる. $m$ が十分に大きいとき $f(x)$ は次式で近似できる（付録 II 参照)

$$
f(x)=\frac{1}{2} \sqrt{x^{2}+4 x}-\frac{x}{2}
$$

$f(x)$ は増加かつ凹関数であり, $f(0)=0, f(\infty)=1$ で ある．個人は，日々のミーティング行動を通じてマッ チング相手の遭遇確率に関する合理的期待を形成する. 式 (32) より, 遭遇確率に関する主観的期待が異なれば, 個人が採用する探索戦略も異なる．個人は遭遇確率の 学習を繰り返しつつ探索戦略を逐次修正する.このよ うな学習過程は, ベイズ学習モデル5)を用いて定式化で きるが，その詳細は別の機会に発表する．いま，すべ ての個人が主観的期待を修正するインセンティブをも たないような合理的期待均衡に収束したと仮定しよう.

このような合理的期待均衡は

$$
\begin{aligned}
\frac{\partial C}{\partial \alpha^{*}}= & \pi^{*}\left(E V^{*}-\rho V^{*}\right) f\left(\frac{\beta}{2 \pi^{*} \alpha^{*}}\right) \\
r V^{*}= & -C\left(\alpha^{*}\right)+2 \pi^{*} \alpha^{*}\left(E V^{*}-\rho V^{*}\right) \\
& \cdot f\left(\frac{\beta}{2 \pi^{*} \alpha^{*}}\right)
\end{aligned}
$$

を同時に満足する $\left(\alpha^{*}, \cdots, \alpha^{*} ; V^{*}, \cdots, V^{*}\right)$ として定義 できる．ただし， $\pi^{*}=\pi^{*}\left(V^{*}\right), E V^{*}=E V^{*}\left(V^{*}\right)$ はそ れぞれ均衡効用 $V^{*}$ を用いて定義した最適合意確率 $(30)$, 最適期待効用 (31) である. 式 (36a) は個人の最適探索行 動に関する条件式を意味している. 式 (36b) は合理的期 待均衡において, 保留効用の現在価値がミーティング 相手を探索することで得られる純期待便益が等しくな ることを意味しており，均衡効用水準を定義している.
式 (36a),(36b) より, 合理的期待均衡において次式が成 立する。

$$
r V^{*}=(2 \eta-1) C\left(\alpha^{*}\right)
$$

ここに, $\eta=\{\partial C(\alpha) / \partial \alpha\} /\{C(\alpha) / \alpha\}>1$ は費用関数 の弾力值であり, 均衡効用は探索情報費用にマークアッ プ率 $2 \eta-1$ を乗じた值となる.

\section{（3）比較静学分析}

交通・通信ネットワークの整備がミーティング均衡

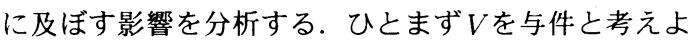
う. ミ一ティング費用 $c$, 保留効用水準 $H$ は合意形成行 動に以下のような影響を及ぼす（付録III参照）。

[命題 1] 期待生涯効用 $V$ を与件とした場合, ミーティ ング費用，保留効用水準が合意形成行動に及ぼす直接 的な影䈉は以下のように評価できる.

$$
\begin{array}{ll}
\left.\frac{\partial \pi}{\partial c}\right|_{V=\text { const. }} \leq 0 & \left.\frac{\partial \pi}{\partial H}\right|_{V=\text { const. }} \leq 0 \\
\left.\frac{\partial E V}{\partial c}\right|_{V=\text { const. }} \leq 0 & \left.\frac{\partial E V}{\partial H}\right|_{V=\text { const. }} \geq 0
\end{array}
$$

命題 1 より, ミーティング費用の上昇はミーティング の合意形成確率を低下させるとともにミーティングの 期待効用を低下させる. 保留効用水準の増加は合意形成 確率を低下させるがミーティングの期待効用が上昇す ることに着目しよう．保留効用水準が上昇すれば，個人 はより効用の高いミーティングを選択するようになり， 結果としてミーティングの期待効用 $E V$ は上昇する.

以上では期待生涯効用を一定と考えて, ミーティン グ費用や保留効用水準がミーティング合意形成行動に 及ぼす影響を分析した．しかし，ミーティング費用の変 化は個人の情報探索行動を変化させ，結果として生涯 効用水準やミーティング生成頻度に影響を及ぼす。ミー ティング費用 $c$ の変化がミーティング均衡に及ぼす影響 は以下の命題に整理できる（付録 III 参照）.

[命題 2] 探索費用関数が条件 $(24)$ を満足するとき，ミ 一ティング費用 $c$ の変化はミーティング均衡に以下のよ うな影筥を及ぼす。

$$
\frac{d V}{d c} \leq 0 \quad \frac{d \alpha}{d c} \leq 0 \quad \frac{d E[n / m]}{d c} \gtreqless 0
$$

命題 2 は任意の $m>0$ に対して成立する. 命題 2 より ミーティング費用の増加は均衡効用, 探索努力を減少 させる. しかし，ミーティング費用がミーティング期待 生起頻度 $1-E[n / m]$ に及ぼす影響は複雑である. いま, $d E[n / m] / d c$ を展開すれば次式を得る（付録 III 参照）。

$$
\frac{\frac{d E}{d c}}{\frac{E}{c}}=-\frac{\frac{\partial E}{\partial x}}{\frac{E}{x}}\left\{\frac{\frac{\partial \pi}{\partial c}}{\frac{\pi}{c}}+\frac{\frac{d \alpha}{d c}}{\frac{\alpha}{c}}+\frac{\frac{\partial \pi}{\partial V}}{\frac{\pi}{V}} \frac{\frac{d V}{d c}}{\frac{V}{c}}\right\}
$$


ここに, $E=E[n / m]$ である. 上式の左辺は, 交通施 設の整備状況がミーティングの生起頻度に及ぼす影響 を変化率を用いて定義したものである. 右辺も同様に 変化率を用いて定義している. 式 (38)の右辺第 1 項は ミーティング費用の変化が合意確率に及ぼす直接的な 効果を, 第 2 項はミーティング費用の変化が探索努力に 影響を及ぼし，結果的にミーティング過程における混 雑現象を克服することにより生じる間接的な効果を表 している. 第 3 項はミーティング費用の変化が期待生 涯効用を変化させ，それがミーティングの合意確率に 及ぼす間接効果であり，2（4）で述べた市場薄の外 部不経済に該当する. 各項の符号を検討することによ り, 交通施設の整備 $(c$ の減少) により右辺第 1 項, 第 2 項は增加するが, 第 3 項は逆に減少することが理解 できる（付録 III 参照）。すなわち，交通施設の整備が ミーティング生起頻度に及ぼす影響は, 第 1 項, 第 2 項で表される直接・間接効果と第 3 項で表される市場 薄の外部不経済の大きさの相対的な関係に依存してい る. 市場薄の外部不経済が第 1 項, 第 2 項を卓越する場 合には, 交通施設の整備は期待生涯効用を増加させる が, ミーティングの生起頻度は減少するという事態が 生じる.このことはフェイス・ツゥ・フェイスのコミュ ニケーションに関する重要な政策課題を示唆している が，それに関しては次節で改めて言及する.

つぎに，情報・通信技術の発展がミーティング均衡 に及ぼす影響を分析しよう．技術水準を表すパラメ一 夕 $\zeta>0$ を導入した費用関数 $C(\alpha: \zeta)$ を考える. 費用関 数は以下の性質を満足すると仮定する.

$$
\frac{\partial C(\alpha: \zeta)}{\partial \zeta} \geq 0, \quad \frac{\partial^{2} C(\alpha: \zeta)}{\partial \zeta \partial \alpha} \geq 0 \quad \frac{\partial \eta(\zeta)}{\partial \zeta} \geq 0
$$

情報・通信技術の発展によりらが減少すると考える.こ こに，以下の命題が成立する（付録 III参照）.

[命題 3] 情報通信技術の变化はミーティング均衡に以 下のような影響を及ぼす.

$$
\frac{d V}{d \zeta} \gtreqless 0 \quad \frac{d \alpha}{d \zeta} \geq 0 \quad \frac{d E[n / m]}{d \zeta} \gtreqless 0
$$

すなわち，情報通信技術の発展（「の減少）により探索 努力 $\alpha$ は減少する. 「の減少は探索努力を減少させるが, 均衡効用が一定である限り合意確率に影響を及ぼさな い. 探索努力の減少はミーティングの生起頻度を減少 させるが，一方で遭遇確率の増加を引き起こす．遭遇 確率の増加は, 結果的にマッチングの期待効用を増加 させる効果を持つ．その結果，「の減少が探索努力の減 少と同時に遭遇確率の増加という拮抗した变化をもた らすため, 均衡効用やミーティングの生起頻度に及ぼ す変化の方向を定性的に確定することはできない.

\section{（4）政策論的含意}

交通施設の整備はミーティング費用の減少をもたら す.しかし，式(38)に示したようにその効果は複雑で ある. ミーティング費用の低減は，命題 1 に示したよ うにミーティングの期待便益 $\bar{v}-c+\varepsilon$ を增加させ合意 確率 $\pi$ を増加させる. また, 個人の探索努力 $\alpha$ も增加す る. その結果, ミーティングの生起頻度は增加し, ミー ティング過程の混雑も増大する。一方, 交通施設の整 備はミーティング過程で得られる期待生涯効用 $V$ を増 加させる方向に作用するが，その結果個人の保留効用 $H$ の增加を招く．すなわち，個人はより高い効用をも たらすミーティングを選択するようになる．命題 1 に 示すように, 保留効用 $H$ の增加は, ミーティング合意 確率 $\pi$ の滅少をもたらす.すなわち, 市場薄の外部不経 済性が生じる。したがって，命題 2 に示すように交通 施設整備がミーティングの期待形成数 $1-E[n / m]$ （言 い換えれば，交通トリップの生成数）に及ぼす影響に ついては，それを増加させる作用と隇少させる作用が 同時に働くため確定的なことは言えない. 交通施設整 備によりフェイス・ツゥ・フェイスのコミュニケーショ ン需要が減少する可能性を否定できない。一方, 命題 2 より，交通施設の整備により 1）ミーティング費用の 減少と，2）保留効用の増大が生じるため個人の長期 効用は必ず增加することが保証される．特に，2）の 効果はより大きな効用を与えてくれるミーティングを 選択することにより達成される効果である．このよう に交通施設の整備がフェイス・ツゥ・フェイスのコミュ ニケーションに及ぼす効果は，1）ミーティング回数 (トリップ生成量) の変化，2）ミーティングの付加価 值の変化に分類できる.すなわち, 命題 2 は, 交通施 設の整備がミーティング行動にもたらす効果は, ミー ティング回数が変化することだけでなく, ミーティン グの付加価值が増加する点にあることを指摘している. このため, 交通需要の増加のみに着目して, 交通施設 の整備便益を評価することは便益の過小評価となろう. 特に, 交通施設を整備してもミーティングの生起頻度 がそれほど変化しない場合には，ミーティングの付加 価值の変化が主要な効果として現れる. 式(37)より均 衡効用水準はマークアップされた探索情報費用に一致 する．このことは情報・通信ネットワークを用いた探 索情報費用を用いて交通施設の整備便益を計量化しう ることを示唆している. 一方, 命題 3 は, 通信・情報 技術の発展は, 必ずしもミーティングの付加価值の上 昇をもたらすとは限らず，より付加価值の低いミーティ ングを形成するにとどまる危険性があることを示唆し ている. ミーティングの付加価值を上昇させるために は交通施設の整備等を通じたミーティング費用の低減 が不可欠である.なお，本研究では情報通信技術を単 
にミーティング相手の探索手段としてのみ位置づけて いる. 本来, 情報通信技術の主たる役割はメッセージ・ 情報の伝達にあり, メッセージ・情報伝達の高度化がも たらす経済効果は多大なものであろう.この種の便益 を測定するためには，交通手段と情報通信手段の選択 を同時に考慮したようなモデルの開発が必要である.

\section{（5）モデルの発展可能性}

現実のミーティング過程は, 非常に複雑な内容と様 式を有しており, 本モデルはその一断面を切り取って 表現したものにすぎない. 本モデルで得られた結論は, 2 人ミーティング, 個人の同質性, ミーティング相手の 歴史的非依存性という箃しい仮定の中で導かれたもの である. 今後, ミーティング過程に関する知見を深め ていくためには，これらの仮定を緩めると同時に代替 的なモデルの枠組みを開発していく必要がある. 本節 では，このようなモデルの発展可能性について若干の 考察を行っておくこととする.

第 1 に，現実のミーティング過程においては学会・組 織等が開催する会議, シンポジウム等の多人数ミーティ ングが重要な役割を果たしている. 多人数ミーティング は, 情報・知識の交換効率を増加させると同時に探索情 報費用を大幅に節約する. 多人数ミーティングが開催 されるためには, それを組織化する個人や組織が必要 となる. 個々人がミーティングに対して支払い意思を持 つ限り，そこに利潤機会やより高度な効用を獲得でき る機会が生まれ, 多人数ミーティングが自発的に形成 される.このような多人数ミーティングや各種の人的 ネットワークの形成メカニズムは探索情報費用の外部 経済性に基づいて表現することが可能である. 第 2 に, 個人の選好の異質性を考慮する必要がある。 また情報 探索技術も個人によって多様に異なるだろう. 個人間 に選好や探索技術の差異が存在すれば，特定の人間に 必要以上のミーティングの申し込みが殺到するという information pollutionが生じたり，ミーティング相手の 探索過程における非効率性の問題が生じる. 特に, 個 人間で選好に異質性が存在する場合, 選好を共有する 個人同士がクラブを形成し，限られたメンバーでミー ティングを繰り返す．多くの人的ネットワークや組織 は, 異なる選好や技術を有する個人がミーティングを 繰り返す中で，自発的に形成されたものである．この ような人的ネットワークの自己組織化過程のある側面 は, 進化論ゲーム17)18)を用いて記述できよう. 第 3 の ミーティング過程の歴史的依存性は, 前述したような クラブや組織の形成過程を記述することにより部分的 ではあるが表現することは可能である. しかし, 個々人 が学習過程を通じて人的なネットワークを拡大してい く過程をランダム・マッチング技術により表現するこ
とは難しい，少なくとも，ランダムマッチングとは異 なる概念を用いた分析枠組みを開発する必要があるだ ろう. 最後に, 異質な個人の相互作用により生じる人 的ネットワークの自己組織化過程は複雑な非線形性を 有していることを指摘しておきたい. 自己組織化の過 程の中で, ある特定の個人やグループがネットワーク 中心となりスタ一的な役割を果たすこともある. 複雑 な非線形性を有するミーティング過程は複数の定常均 衡解を有しており, 交通施設の整備は人的ネットワー ク構造を基本的に変化させる可能性がある.このよう なネットワークの自己組織化とその分岐に関する分析 が今後重要な研究課題になると考える.

\section{6. おわりに}

本研究では，同質な個人により「個人情報・近視眼 的戦略・逐次決定」方式で行われる 2 人ミーティング 過程をとりあげ，そこで生じるミーティング均衡の特 性について理論的な分析を試みたものである. そのた めに, フェイス・ツゥ・フェイスのコミュニケーション が, ミーティング相手の探索行動と合意形成行動により 構成されることを指摘し, 個人のミーティング行動を Bellmanの最適性原理を用いて表現した。 さらに, 長 期定常状態において実現するミーティング均衡を合理 的期待均衡として記述した. 本研究の理論分析におけ る重要な知見の 1 つは, 交通施設整備が交通需要の量 的な変化だけでなく, ミーティングの付加価値の上昇 という質的な変化をもたらすことを明らかにした点に ある. 著者等の知る限り, このような交通施設整備に よるフェイス・ツゥ・フェイスのコミュニケーションの 質的な変化を指摘した研究事例は見あたらない. なお, 5. (5) において今後の研究課題について考察したが, 本研究で提案したモデルの拡張・発展という点に焦点 を絞っても以下のような課題が残されている. 第 1 に, 本モデルではある 1 つの都市の中で繰り返されるミー ティング過程を対象としたが, 今後, 空間や都市シス テムを明示的に組み込んだようなモデル化が必要とな ろう. 筆者らは, 非常に初歩的な段階ではあるが, 都 市システムにおけるミーティング過程のモデル化を試 みている21)が, 本研究で指摘したような外部経済性を 考慮したようなモデルの拡張が必要となろう. 第 2 に, 家計だけでなく企業間・企業内部でのミーティング過程 のモデル化も必要である. 特に, ミーティング過程にお ける集積の経済性に関するミクロ経済分析は, 都市核 や都市システムの自己組織化の過程を理解するための 基礎研究になろう. 最後に, 実証分析が残されている. ミーティング過程を記述する上で核となるマッチング 行動に関しては, 小林他が提案したランダム・マッチン 
グモデル6)が適用可能である. 残念ながら, 都市内で繰 り返されているミーティングに関して利用可能なデー 夕は極めてそしいのが実状である. ミーティング調查 の方法論も含めて, 実証分析に向かっても極めて多く の研究課題が残されていると言わざるを得ない．この ように今後に残された研究課題は極めて多い. しかし, 本論文を通じて, 従来その重要性が指摘されながらも, ほとんど研究がなされなかったフェイス・ツゥ・フェイ スのコミュニケーション過程の数学的モデル化の可能 性について一つの方向性を示し得たと考える.

\section{付録 I 定常再帰方程式の導出}

定常状態では $V(t+\Delta t+T)=V(t+\Delta t)(T>0)$ が 成立すると仮定しょう. 式 $(21)$ において積分を実行す れば $R(t+\Delta t)=E V+v V(t+\Delta t)$ が成立する. ただ し, $v=\beta /(r+\beta)$ である. 式(23) より次式を得る.

$$
\begin{gathered}
\frac{r \Delta t}{1+r \Delta t} V(t)=\max _{\alpha \geq 0, H}\{-C(\alpha) \Delta t \\
+\frac{\pi q \Delta t}{1+r \Delta t}[E V+(v-1) V(t+\Delta t)] \\
\left.+\frac{1}{1+r \Delta t}\{V(t+\Delta t)-V(t)\}\right\} .
\end{gathered}
$$

上式の両辺を $\Delta t /(1+r \Delta t)$ で除することにより

$$
\begin{aligned}
& r V(t)=\max _{\alpha \geq 0, H}\{-C(\alpha)(1+r \Delta t)+\pi q[E V \\
& \left.+(v-1) V(t+\Delta t)]+\frac{V(t+\Delta t)-V(t)}{\Delta t}\right\}
\end{aligned}
$$

を得る. 定常状態で, $\lim _{\Delta t \rightarrow 0} V(t+\Delta t)=V(t)=V$, $\lim _{\Delta t \rightarrow 0}\{V(t+\Delta t)-V(t)\} / \Delta t=0$ が成立することに 留意すれば, $\Delta t \rightarrow 0$ の極限において次式が成立する.

$$
r V=\max _{\alpha \geq 0, H}\{-C(\alpha)+\pi q(\alpha)(E V-\rho V)\}
$$

ただし, $\rho=r /(r+\beta)$ である.

\section{付録 II $E[n / m]$ の導出}

$P(m+1)=0$ が成立することに留意すれば, $E\left[n^{2}\right]=$ $\sum_{n=0}^{m}(n+1)^{2} P(n+1), E[n]=\sum_{n=0}^{m}(n+1) P(n+1)$ が成立. また, $E[n(2 n+1)]=2 E\left[n^{2}\right]+E[n]$ は明らか. 一方, 式(4),(10),(11)より次式を得る.

$$
\begin{aligned}
& E[n(2 n+1)]=\sum_{n=0}^{m}(n+1)(2 n+3) P(n+1) \\
& =\sum_{n=0}^{m}(n+1)(2 n+3) \frac{2 m \beta(m-n)}{\bar{\alpha} \pi(n+1)(2 n+3)} P(n) \\
& =\frac{2 m \beta}{\bar{\alpha} \pi} \sum_{n=0}^{m}(m-n) P(n)=\frac{2 m \beta}{\bar{\alpha} \pi}\{m-E[n]\}
\end{aligned}
$$

$\bar{\alpha}=\alpha+\hat{\alpha}$ である. したがって, 次式を得る.

$$
E\left[n^{2}\right]=-\frac{E[n]}{2}+\frac{m \beta}{\bar{\alpha} \pi}\{m-E[n]\}
$$

両辺を $m^{2}$ で割り $m \rightarrow \infty$ の極限をとれば次式が成立.

$$
E\left[\left(\frac{n}{m}\right)^{2}\right]=\frac{\beta}{\bar{\alpha} \pi}\left\{1-E\left[\frac{n}{m}\right]\right\}
$$

一方, 式 (34)の両辺を $x$ に関して微分すれば

$$
\frac{d E\left[\frac{n}{m}\right]}{d x}=\frac{m}{x} \operatorname{Var}\left[\frac{n}{m}\right]
$$

を得る.ここに, $\operatorname{Var}[n / m]=E\left[(n / m)^{2}\right]-E[n / m]^{2}$ は分散である. 任意の $m$ に対して $0 \leq E[n / m] \leq 1$, $0 \leq E\left[(n / m)^{2}\right] \leq 1$ が成立し, 分散 $\operatorname{Var}[n / m]$ は任意 の $m$ に関して $0 \leq \operatorname{Var}[n / m] \leq 1 . E[n / m]$ は $x$ の関 数 $0 \leq f(x) \leq 1$. 式(II.2)より, $\lim _{x \rightarrow 0} \partial f(x) / \partial x=$ $\infty, \lim _{x \rightarrow \infty} \partial f(x) / \partial x=0$. 中間値の定理より, 任意の $\infty>u>0$ に対して $d E[n / m] / d x=u$ となる $x$ が存在 する. 任意の $m$ に対して $d E[n / m] / d x=u$ が成立する ためには $\lim _{m \rightarrow \infty} \operatorname{Var}[n / m]=0$ でなければならない. すなわち, 十分大きな $m$ に対して近似的に

$$
\left\{E\left[\frac{n}{m}\right]\right\}^{2}+\frac{\beta}{\bar{\alpha} \pi} E\left[\frac{n}{m}\right]-\frac{\beta}{\bar{\alpha} \pi}=0
$$

が成立する. 式(II.3)より次式を得る.

$$
E\left[\frac{n}{m}\right]=\frac{1}{2} \sqrt{\left(\frac{\beta}{\bar{\alpha} \pi}\right)^{2}+4 \frac{\beta}{\bar{\alpha} \pi}}-\frac{1}{2} \frac{\beta}{\bar{\alpha} \pi}
$$

\section{付録 III 命題の証明}

（命題 $1 ） \pi$ の定義より, $\partial \pi / \partial c \leq 0, \partial \pi / \partial H \leq 0$ は明 白. $y=\bar{v}-\delta(c+H)$ を定義する. $\delta \gamma=1$. 式(18)よ り $\partial E V / \partial c=-1+\left(y \phi / \Phi+\phi^{2} / \Phi^{2}\right)$. Mill's ratio $\left.{ }^{19}\right)$ の 公式より任意の $y$ に対して $1 \geq y \phi / \Phi+\phi^{2} / \Phi^{2} \geq 0$ が 成立 ${ }^{20)}$. これより $\partial E V / \partial c \leq 0$. 同様に, $\partial E V / \partial H=$ $y \phi / \Phi+\phi^{2} / \Phi^{2} \geq 0$ も自明.（命題 2 ）まず, 以下の導関 数の符号を評価する. i) 式(II.2) より $\partial E[n / m] / \partial x \geq 0$. ii) 命題 1 より $\partial(E V-\rho V) / \partial c=y \phi / \Phi+\phi^{2} / \Phi^{2}-1 \leq 0$ iii) 仮定より $\partial C / \partial \alpha \geq 0, \partial^{2} C / \partial \alpha^{2} \geq 0, \partial \eta / \partial \alpha \geq 0$. iv) $f(x)$ が単調増加凹関数, かつ $f(0)=0$ であることよ り, $f-(\partial f / \partial x) x \geq 0$ が成立. 式(36a),(37) の両辺を 均衡解 $x^{*}, \alpha^{*}, V^{*}$ の近傍で全微分すれば

$$
\begin{aligned}
& \Xi_{c}^{a} d c+\Xi_{V}^{a} d V-\Xi_{\alpha}^{a} d \alpha=0 \\
& r d V-\Xi_{\alpha}^{b} d \alpha=0
\end{aligned}
$$

を得る. $\Xi_{c}^{a}=\left\{f^{*}-\left(\partial f^{*} / \partial x^{*}\right) x^{*}\right\}\left(\partial \pi^{*} / \partial c\right)\left(E V^{*}-\right.$ $\left.\rho V^{*}\right)+\pi^{*} f^{*}\left\{\partial\left(E V^{*}-\rho V^{*}\right) / \partial c\right\} \leq 0, \Xi_{\alpha}^{a}=$ $\partial^{2} C^{*} / \partial \alpha^{2}+\pi^{*}\left(E V^{*}-\rho V^{*}\right)\left(\partial f^{*} / \partial x^{*}\right)\left(x^{*} / \alpha^{*}\right) \geq 0$, $\Xi_{V}^{a}=\pi^{*} f\left(x^{*}\right) \partial\left(E V^{*}-\rho V^{*}\right) / \partial V^{*}+\left(\partial \pi^{*} / \partial V^{*}\right)\left(E V^{*}-\right.$ $\left.\rho V^{*}\right)\left\{f^{*}-\left(\partial f^{*} / \partial x^{*}\right) x^{*}\right\} \leq 0, \Xi_{\alpha}^{b}=\left(2 \partial \eta^{*} / \partial \alpha^{*}\right) C^{*}+$ $\left(2 \eta^{*}-1\right)\left(\partial C^{*} / \partial \alpha^{*}\right) \geq 0$ である. 式(III.1)より

$$
\begin{aligned}
& \frac{d \alpha}{d c}=\frac{\Xi_{c}^{a}}{\Xi_{\alpha}^{a}-\Xi_{V}^{a} \Xi_{\alpha}^{b} / r} \leq 0 \\
& \frac{d V}{d c}=\frac{\Xi_{\alpha}^{b}}{r} \frac{\partial \alpha}{\partial c} \leq 0 .
\end{aligned}
$$


一方, $\partial E[n / m] / \partial c=-\left(\partial f^{*} / \partial x^{*}\right) x^{*}\left\{\left(\partial \alpha^{*} / \partial c\right) / \alpha^{*}+\right.$ $\left.\left(\partial \pi^{*} / \partial c\right) / \pi^{*}+\left(\partial \pi^{*} / \partial V^{*}\right)\left(\partial V^{*} / \partial c\right) / \pi^{*}\right\} . \partial \alpha^{*} / \partial c \leq$ $0, \partial \pi^{*} / \partial c \leq 0, \partial V^{*} / \partial c \leq 0, \partial \pi^{*} / \partial V^{*}<0$ より $\partial E[n / m] / \partial c$ の符号は不定. 両辺を $E / c$ で割れば式 (38) を得る.（命題 3 ）均衡解の近傍で

$$
\begin{aligned}
& \Xi_{\eta}^{a^{\prime}} d \zeta-\Xi_{V}^{a^{\prime}} d V-\Xi_{\alpha}^{a^{\prime}} d \alpha=0 \\
& r d V-\Xi_{\zeta}^{b^{\prime}} d \zeta-\Xi_{\alpha}^{b^{\prime}} d \alpha=0
\end{aligned}
$$

を得る.なお，仮定より $\Xi_{\zeta}^{a^{\prime}}=\partial^{2} C^{*} / \partial \alpha \partial \zeta \geq$ $0, \quad \Xi_{\alpha}^{a^{\prime}}=-\pi^{*}\left(E V^{*}-\rho V^{*}\right)\left(\partial f^{*} / \partial x^{*}\right)\left(x^{*} / \alpha^{*}\right)-$ $\partial^{2} C^{*} / \partial \alpha^{2} \leq 0, \Xi_{V}^{a^{\prime}}=\pi^{*} f\left(x^{*}\right) \partial\left(E V^{*}-\rho V^{*}\right) / \partial V^{*}+$ $\left(\partial \pi^{*} / \partial V^{*}\right)\left(E V^{*}-\rho V^{*}\right)\left\{f^{*}-\left(\partial f^{*} / \partial x^{*}\right) x^{*}\right\} \leq 0$, $\Xi_{\zeta}^{b^{\prime}}=2(\partial \eta / \partial \zeta) C^{*}+(2 \eta-1) \partial C^{*} / \partial \zeta \geq 0, \Xi_{\alpha}^{b^{\prime}}=$ $(2 \eta-1) \partial C^{*} / \partial \alpha \geq 0$. 式(III.2)より次式が成立する.

$$
\begin{aligned}
& \frac{d \alpha}{d \zeta}=\frac{\Xi_{\zeta}^{a^{\prime}}-\Xi_{V}^{a^{\prime}} \Xi_{\zeta}^{b^{\prime}} / r}{\Xi_{\alpha}^{a^{\prime}}+\Xi_{V}^{a^{\prime}} \Xi_{\alpha}^{b^{\prime}} / r} \geq 0 \\
& \frac{d V}{d \zeta}=\frac{\Xi_{\zeta}^{a^{\prime}} \Xi_{\alpha}^{b^{\prime}}+\Xi_{\alpha}^{a^{\prime}} \Xi_{\zeta}^{b^{\prime}}}{r \Xi_{\alpha}^{a^{\prime}}+\Xi_{V}^{a^{\prime}} \Xi_{\alpha}^{b^{\prime}}} \gtreqless 0 .
\end{aligned}
$$

命題 2 と同様の方法で $d E[n / m] / d \eta$ の符号が不定である ことを示すことができる.

\section{参考文献}

1) 小林潔司：知識社会における交通行動：課題と展望, 土 木計画学研究・論文集, No.12, pp.1〜13, 1995.

2) Daganzo, C. F. and Sheffi, Y.: On stochastic models of traffic assignment, Transportation Science, Vol. 11, pp. 253-255, 1977.

3) Fisk, C.: Some developments in equilibrium traffic assignment, Transportation Research, Vol. 14, B(3), pp. 243-255, 1980.

4) 小林潔司: 不完備情報下における交通均衡に関する研究, 土木計画学研究・論文集, No.8, pp. 81-88, 1990.

5) Kobayashi, K.: Information, rational expectations and network equilibria, The Annals of Regional Science, Vol. 28, pp. 369-393, 1994.

6) 小林潔司, 喜多秀行, 多々納裕一: 送迎・相乗り行動のた めのランダム・マッチングモデルに関する研究, 土木学 会論文集, No. 536/IV-31, pp. 49-58, 1996.
7) 森川高行: 個人選択モデルの再構築と新展開，土木計画 学研究・論文集, No. 12, pp. 15-27, 1995.

8) McMillan, J. and Rothschild, M.: Search, in: Aumann, R. J. and Hart, S. (eds.), Handbook of Game Theory, North-Holland, Vol. 2, pp. 905-927, 1994.

9) Diamond, P. A. : A Search Equilibrium Approach to the Micro Foundation of Macroeconomics, The MIT Press, 1984.

10) Mortensen, D. T. : The matching process as a noncooperative bargaining game, in: McCall, J. J. (ed.), The Economics of Information and Uncertainty, pp. 233-258, University of Chicago Press, 1982.

11) Howitt, P. : Costly Search Recruiting, in: Howitt, P., The Keynesian Recovery and Other Essays, pp. 177196, Philip Allan, 1990.

12) Roth, A. and Sotomayor, M. A. O.: Two-Sided Matching, A Game-Theoretic Modeling and Analysis, Cambridge University Press, 1990.

13) Binmore, K. and Dasgupta, P. (eds.): The Economics of Bargaining, Basil Blackwell, 1987.

14) Bellman, R.: Dynamic Programming, Princeton University Press, 1957.

15) Kreps, D. M.: Game Theory and Economic Modelling, Oxford University Press, 1990, 高森寛, 大住栄治, 長野 透訳: 経済学のためのゲーム理論, マグロウヒル, 1993.

16) Muth, J. F.: Rational expectations and the theory of price movements, Econometrica, Vol. 29, pp. 315-335, 1961.

17) Weibull, J. W.: Evolutionary Game Theory, The MIT Press, 1995.

18) Vega-Redondo, F.: Evolution, Games and Economic Behaviour, Oxford University Press, 1996.

19) Mills, J. F.: Table of the ratio: Area to bounding ordinate for any portion of normal curve, Biometrica, Vol. 18, pp. 395-400, 1926.

20) Maddala, G. S.: Limited-Dependent and Qualitative Variables in Econometrics, pp. 165-170, Cambridge University Press, 1983.

21）福山敬，小林潔司: 地域間の人的交流行動分析のための ランダム・マッチングモデルに関する研究, 第 32 回都市 計画学会学術研究論文集, pp. 139-144, 1997.

(1997. 5. 6 受付)

\title{
COMMUNICATION PROCESSES BY FACE-TO-FACE CONTACTS: A THEORETICAL PERSPECTIVE
}

\author{
Kiyoshi KOBAYASHI, Kei FUKUYAMA and Kakuya MATSUSHIMA
}

\footnotetext{
The face-to-face communication processes are assumed to be composed of two distinct processes: matching and agreement processes. In the former process, individuals are encouraged to search for meeting partners, while, in the latter, the matched pairs negotiate whether they meet each other. The individual behaviour in a dynamic context is described by using Bellman's principle of optimality. The equilibrium concept emerges as a stationary state where all individuals behave with rational expectations in noncooperative fashions. A comparative static analysis is made to evaluate the impacts of policy variables upon the individual interactability.
} 